\title{
Szakolczai György: John Maynard Keynes, a nemzetközi gazdaság keynesi rendje és a Nemzetközi Valutaalap
}

\section{Közgazdasági Szemle Alapítvány, Budapest, 2018, 420 o.}

A könyv olvasója szakkönyvek esetén szokatlan, egyedi élményben részesül. A nemzetközi gazdasági kapcsolatok alapvető fontosságú kérdéseit tárgyaló mű egyúttal érdekfeszítő olvasmány is. A szerző meggyőződése, hogy Keynes e kérdéskörben kifejtett nézetei csak életpályája egészének ismeretében tárgyalhatók, ezért részletes képet ad életének és szakmai tevékenységének legfontosabb elemeiről, fordulatairól. Ez a pályakép a szakmailag sok kérdést a jelenlegi fősodortól eltérően, a begyökeresedett megoldásokat megkérdőjelezhető módon tárgyaló szakkönyvet izgalmas, lebilincselő olvasmánnyá teszi.

A húsz fejezet öt fő részre oszlik. Az első rész öt fejezete Keynes életútját és életművét mutatja be. A szerző fontosnak tartja a család szerepét, édesapjának a cambridge-i egyetemen betöltött posztját és azt a tényt, hogy édesanyja az elsők között szerzett nőként diplomát, és anyaként is fontos közéleti szerepeket vállalt, Cambridge polgármestere lett. Fiának közéleti érdeklődésére, a közjó szolgálata iránti elkötelezettségére mindez bizonyosan hatással volt. Részletesen szól az I. rész Keynes etoni és cambridge-i tanulmányairól. Meglepve olvastam matematikai kiválóságáról, hiszen a köztudatban az él, hogy müvei verbális jellegüek, nem használ matematikai apparátust. Szakolczai szerint ez is igazolja, hogy a formalizált, elméleti jellegủ megközelítéssel szemben mindig a problémák valamennyi elemére kiterjedő, gyakorlatias megoldásokat kereste.

E megközelítést igazolja Keynes szerepe az első világháborút lezáró versailles-i tárgyalásokon, amelyeken a brit küldöttség pénzügyi kérdésekért felelös vezetőjeként vett részt, majd lemondott, miután azt tapasztalta, hogy országaik közvéleményére - büntessük keményen a németeket - tekintettel a tárgyaló feleket nem lehetett meggyőzni a Keynes által javasolt méltányos, de a világgazdaság megrázkódtatását elkerülő megoldásról. Keynes is egyetértett a jóvátétel indokoltságával, de fontosnak tartotta, hogy annak mértéke ne jelentsen elviselhetetlen terhet Németország számára. Felhívta a figyelmet arra is, hogy Franciaország és Nagy-Britannia azért is ragaszkodik a hatalmas összegü jóvátételhez, mert az Egyesült Államokkal szembeni adósságaik törlesztéséhez volt szükségük többletforrásokra. Arra a következtetésre jutott, hogy a világgazdaság egésze - és így a hiteleket nyújtó Egyesült Âllamok - számára 
is igazolja, hogy előnyös volna az adósságok egy részének az elengedése. Ez a gondolat Keynes későbbi elgondolásaiban is megjelenik, egyik bizonyítékát adva a szerző véleményének, amely szerint Keynes munkásságát egységes egésznek kell tekinteni.

A tárgyalások érdekes eleme a meghatározó szereplők - Clemenceau, Lloyd George és Wilson - egyéniségének, gondolkozásának bemutatása Keynes feljegyzései alapján. A könyv a Nemzetközi Valutaalap megalakulást előkészítő tárgyalások elemzésekor (és majd a későbbiekben is) igazolja, hogy az ilyen megbeszéléseken az eltérő politikai, gazdasági, filozófiai nézetek mellett rendkívül nagy jelentősége van a fö tárgyalópartnerek egyéniségének is.

A 4. fejezet bemutatja azokat az írásokat, amelyekben Keynes elemzi a szerződés negatív gazdasági következményeit, érvel a békeszerződés revíziója mellett. Ezeket az írásokat áthatja, hogy a partikuláris érdekekkel szemben Keynes mindig a világ egésze számára jótékony hatással járó megoldások mellett állt ki. Az adósságprobléma kapcsán kifejtettek viszont szerintem némi árnyalást igényelnek. A leírtak alapján Keynes csak akkor tartja indokoltnak külföldi hitelek felvételét, ha azok nyers-, illetve alapanyagtermelő ágazatok beruházásait finanszírozzák. Példái: amerikai búza, ceyloni teatermelés, gumiültetvények, arany- és ónbányászat. Ezek jó példák a 19. században, a 20. század második felétől azonban több példa - Japán, Dél-Korea, további ázsiai országok, de napjainkra talán Magyarország is - szól amellett, hogy gyorsabb gazdasági növekedést, felzárkózást tesz lehetővé, ha belföldi források mellett külföldi forrásokat is be lehet vonni a gazdaság fejlesztésébe. Persze fontos - amint Szakolczai is kiemeli -, hogy ezek a hitelek az exportképesség javulását eredményezzék, ilyen beruházások azonban a feldolgozóiparban, sőt egyes szolgáltatási területeken is vannak. A kérdéskör részletes elemzésére itt nincs lehetőség - jobb a vállalati, mint az állami hitelfelvétel, jobb a közvetlenül beruházásra bevont tőke, mint a hitel, stb. -, de összességében a külföldi források bevonása (az adósságteremtés) hasznos lehet a gazdaság számára.

Keynes [1937/1965] fő művét jól ismertnek tekintve, a könyv nem foglalkozik részletesen vele, de kitér következtetéseinek, jövőképének egyes elemeire. Âltalában meggyőzően mutatja be, miként valósultak, illetve nem valósultak meg a gazdasági javaslatok, elörejelzések. Nem látszik azonban igazoltnak a járadékosok lassú kimúlására - eutanáziájára - vonatkozó elörejelzés, az utóbbi évtized hozam- és kamatcsökkenése nem elegendő ennek igazolására. Piketty [2015] nagy visszhangot keltő munkája mintha ennek ellenkezőjét igazolná.

Az I. rész Keynes életének helyenként regényesen érdekes bemutatása mellett munkáinak elemzésével igazolja, hogy gondolkodásában mindig az emberiség egésze számára legjobbnak tartott megoldások keresése vezette.

A II. rész A nemzetközi gazdaság keynesi rendjének alapelvei címet kapta. A szerző a Valutaalapról folytatott előkészítő tárgyalások anyagaiból vezeti le az elmélet lényegi elemeit. Úttörő jellegű munkát végez, amikor egységes rendbe foglalja a különböző publikációkban található gondolatokat. Ez egészen különleges, hatalmas anyagot feldolgozó, rendszerbe foglaló munka. A Keynes-terv első változatának ismertetése előtt több előkészítő anyagot mutat be a szerző, amelyek révén megismerhetjük az elgondolások legfontosabb elemeit. Ezáltal is igazolja, hogy a keynesi életmủ egységes egész, 
és amint az egyes nemzetgazdaságok tekintetében a foglalkoztatás és így a növekedés, a jólét növelését célzó megoldások mellett érvel, úgy a világgazdaság egészét illetően az egyensúlytalanságokból eredő válságok és gazdasági visszaesés elkerülését, minimalizálását tekinti célnak.

Legfontosabb tétele, hogy a fenti célt szolgáló gazdasági rendnek - a hitelfelvevő és esetenként túlzott mértékủ adósságot felhalmozó országok mellett - a hitelezői pozícióban lévő országok számára is szükségesek a gazdaságpolitikai változtatások. A Nemzetközi Valutaalap alapszabálya és gyakorlata azonban csak az adósságválságba kerülö és emiatt az IMF-hez forduló országok számára írt elő - a hitelnyújtás feltételeként kötelező jellegű gazdaságpolitikai, költségvetési, árfolyam-politikai lépéseket. Keynes javaslataival szemben nem sikerült olyan rendszert létrehozni, amely kötelezni tudná a tartósan fizetésimérleg-többlettel rendelkezö országokat gazdaságpolitikájuk, annak egyes elemeinek a megváltoztatására. Az évente folytatott (IV. cikkely szerinti) konzultációk eredményei alapján a Valutaalap megfogalmaz ajánlásokat, ezeket azonban a hitel felvételével nem kötelezett országok (hasonlóan például az OECD javaslataihoz) jó esetben is csak felemásan követik. A következtetések - az érzékeny árfolyamjavaslatok kivételével - nyilvánosak, így az érdeklődők meggyőződhetnek erről.

A szerző bemutatja, hogy a Keynes által javasolt rendszer konzisztens módon biztosítja az előzőkben tárgyalt cél érvényesülését. Lényeges eleme, hogy a túlzott mértékü egyensúlytalanság kialakulásának első jeleinél már beavatkozásokat lát indokoltnak mind a hiányt, mind pedig a többletet felmutató országok esetében. Az éves külkereskedelmi forgalom negyedét elérő hiány, illetve többlet esetében az érintett országok lehetőséget kapnak a rögzített valutaárfolyamokon alapuló rendszerben valutájuk legfeljebb 5 százalékos le-, illetve felértékelésére, míg az 50 százalékot elérő hiány esetében az 5 százalékos kiigazítás kötelező lenne. Ez a mechanizmus már viszonylag kis hiány, illetve többlet esetén javítaná a hiányországok exportlehetőségeit, és csökkentené importkeresletüket, növelve a belföldi értékesítési lehetőségeket, míg a hitelezői pozícióban lévő országokban a belföldi keresletet ösztönző módszerek - ezek megválasztását a javaslat az érintett országokra bízza - biztosítanák a növekedésösztönző, expanzív környezetet. Ezért mondja Szakolczai, hogy a kiigazításban a hitelnyújtó országoknak is részt kell venniük, ez azonban számukra „édes teher”.

A javasolt rendszer kritikus eleme, hogy folyamatos valutaspekulációra vezetne. A könyv szerzője szerint a viszonylag kis mértékek miatt a spekuláció nem volna nagymértékü, a tapasztalatok azonban azt mutatják, hogy tizedszázalékos nyereségért is hatalmas tőkék mozdulnak meg. Keynes rendszerének többek közt ezért is szerves eleme a tőkemozgások nemzetközi felügyelet alá helyezése. Ez a felügyelet lehetővé tenné a ,jó" tőkeáramlást (a tőkefelesleggel rendelkező országok beruházásai olyan országokba, amelyek velük szemben adóspozícióban vannak), és nem engedélyezne „rossz” tőkemozgásokat, tőkemenekítést. A szerző ennek példájaként említi a devizatartalékok képzését is. Ezt az állítást pontosítani indokolt, hiszen a tartalékképzés valóban csökkenti a nettó külföldi adósságot, de csak akkor tüntetné el (és tenné az országot tőkekihelyezővé), ha mértéke nagyobb lenne a bruttó adósságnál.

A tőkeforgalom ellenőrzése kapcsán (amit a könyv kívánatos rendszerként tárgyal, bár jelzi, hogy a gyakorlati megvalósítás napjainkban szinte lehetetlen) érdemes kitérni 
az ellenérvekre is. Minden korlátozás hatékonyságveszteséggel jár, megakadályozhat összességében pozitív hatású beruházásokat, részben a direkt tiltás miatt, részben pedig azért, mert a tőke szabad kivonásának bizonytalansága következtében a tőketulajdonosok egy része nem használja ki a keletkező kedvező lehetőségeket.

A II. rész a Keynes-terv első változatának - amelyet tartalmaz a kötet függeléke részletes elemzésével zárul. A megelöző fejezetekben tárgyalt alapelvek vizsgálatával együtt talán ez a könyv legtöbb szakmai érdekességet, továbbgondolásra érdemes gondolatot tartalmazó része.

A III. rész az Angol-amerikai vita a Nemzetközi Valutaalapról címet kapta. A tárgyszerü beszámolót sejtető cím alapján sok olvasó várhatóan meglepődik, hogy a részletes és pontos beszámoló mellett izgalmas olvasmányt is nyújt ez a rész. A szerző lépésről lépésre mutatja be az álláspontok alakulását, azok egymásra hatását, illetve esetenként - ahogy ő fogalmaz - a süketek párbeszédét.

Megismertet az amerikai főszereplö, H. D. White életútjával. Elsőgenerációs amerikaiként és elsőgenerációs értelmiségiként lett rövid egyetemi pályafutás után az amerikai pénzügyminisztérium (Treasury) vezető tisztségviselöje, és ő alakította ki az előkészítő tárgyalásokon képviselt amerikai véleményt. Keynesszel ellentétben munkássága, publikációi nem hagytak maradandó nyomot, mondhatni, nem voltak „egy súlycsoportban”, paradox módon a létrejött nemzetközi rendszer alapvetően mégis az ő javaslatai szerint alakult. Ennek egyik oka nyilván az, hogy elképzelései sokkal inkább összhangban voltak az uralkodó közgazdasági nézetekkel, a fö ok azonban az lehetett, hogy a háború után gazdaságilag a világ domináns hatalmává vált Egyesült Államok érdekeinek az ő elképzelései sokkal inkább megfeleltek, mint Keynes radikális javaslatai.

A könyv egyenként tárgyalja az előkészítés során készült, lépésenként bizonyos pontokon módosuló változatokat. A szerző legfontosabb következtetése, hogy White aranyalapra épülö, egyensúlyhiány esetén a kiigazítás terhét egyoldalúan az adósi pozícióban lévő országokra terhelő rendszere világgazdasági szinten (tehát nem csupán a válságba került országban) okozhat gazdasági visszaesést a kereslet visszaesése miatt, szemben Keynes klíringunióra épülő rendszerével, amelyben az automatikus hitellehetőség (overdraft) engedélyezése lehetőséget ad a fokozatos kiigazításra és így az azonnali nagymértékű visszaesés elkerülésére.

Az egyes változatok bemutatásakor - beleértve az amerikai tervre reagáló Keynesterv második változatát - a szerző világossá teszi, hogy Keynes elképzeléseit tartja jobbnak, nemcsak egészében, hanem egyes elemeit tekintve is. Hasonlóan a Keynesés White-féle javaslatok valamennyi változatához, amelyek mindig az elképzelések megvalósításának pozitív hatásait mutatják be, a könyv - a szerző álláspontjának megfelelően - Keynes javaslatai esetében azok pozitív, míg a White-féle elképzelések esetén azok hátrányos következményeit emeli ki. Nyilván mindhárman tisztában voltak azzal, hogy gazdaságpolitikai beavatkozások, a gazdasági élet, a nemzetközi gazdasági kapcsolatok alakulását szabályozó megoldások esetén egészen ritka kivételektől eltekintve nincsenek csak pozitív következményekkel járó változatok. Jellemzőbb, hogy minden megoldásnak vannak előnyös és hátrányos következményei, és döntéseket ezek gondos mérlegelésével, a pozitív és a negatív hatások egybevetésével, súlyozásával célszerü hozni. 
A meggyőzés szándékával az előnyök, illetve a rosszabbnak tartott változatok esetén a hátrányok bemutatására koncentráló tárgyalásmód megkímél a passzív olvasástól, felkínálja az aktív, a leírtak sokoldalú továbbgondolására késztető olvasást. Már említettem a Keynes által javasolt árfolyam-kiigazítási rendszer spekulációs kockázatát, a tőkeforgalom ellenőrzése következtében beruházások esetleges elmaradását. A példák hosszan sorolhatók volnának, további illusztrációként gondoljunk a Keynes-féle export-, illetve importilleték termelés-visszafogó hatására, amely ellentétes a javaslat egészének növekedéstámogató alapcéljával. White azonnali kiigazításra épülő rendszere a nyilvánvaló outputveszteség ellenére előnyös lehet abból a szempontból, hogy elkerüli a fokozatos kiigazítás esetlegesen elhúzódó válságra vezető kockázatát.

Ezek a példák számomra csak megerősítik, hogy a III. rész a javaslatok születésének, módosulásának izgalmas bemutatása mellett komoly szellemi kihívást is jelent a témában elmélyedni kívánó olvasónak.

A IV. rész A Nemzetközi Valutaalap megalapítása címet kapta. E rész első fejezete az angol és amerikai elképzelések megvitatása után elfogadott közös nyilatkozatot ismerteti. Bemutatja, hogy a megegyezés kényszere miatt Keynesnek fel kellett adnia a rendszer olyan kulcselemeit, mint a klíringunió és az automatikus hitellehetőség (overdraft), és el kellett fogadnia az általa hibásnak tartott aranystandardot. Ugyanakkor a nyilatkozat, az ahhoz füzött angol-amerikai megjegyzések alapján a szerző bizonyítja, hogy a nyilatkozat megőrizte a Keynes-féle javaslat számos fontos elemét.

Bár a megállapodást előkészítő Atlantic City-i konferencia ismét felszínre hozta az angol-amerikai ellentéteket, Bretton Woodsban a nemzetközi tárgyalások végül eredményre vezettek, a szerző szerint azonban itt megegyezési kényszer volt. Az IMF alapokmányát ismertető fejezetben a könyv bemutatja, milyen elemekben tartalmaz az alapvetően White-féle elgondolásra épülő rendszer számos fontos keynesi elvet.

$\mathrm{Az}$, hogy ezek az elvek a későbbiekben nem vagy csak kevéssé érvényesültek, a szerző meggyőződése szerint azért történhetett, mert váratlan halála után Keynes hiányzott az IMF igazgatóságából, és nem akadt az elveit hozzá hasonló következetességgel és tekintéllyel képviselő utódja.

$\mathrm{Az} \mathrm{V}$. rész $\mathrm{A}$ hármas tragédia és elözményei cím alapján is érezhetően a könyv regényes vonulatához tartozik. A 15. fejezet White külpolitikai tevékenységét tekinti át, ugyanis - pénzügyminisztériumi szerepéből nem következő módon - e téren is meghatározó befolyása volt.

A könyv bemutatja a White által kidolgozott, Morgenthau nevével jelzett, Németország jövőjét meghatározni kívánó tervet, amely a német ipar újraindulását kívánta megakadályozni, és az országot mezőgazdasági kisbirtokok országává próbálta tenni. A terv az amerikai hadügy- és külügyminisztérium ellenállása miatt végül megbukott. Érdekes mozzanatokat ismerhetünk meg a szövetségesekkel, illetve az amerikai adminisztráción belül folytatott vitákról. Negatívan ítéli meg a könyv White szerepét a kínai aranyszállítások lassú elindításában, amelyek így nem tudták elérni szándékolt céljukat, a kínai infláció megállítását. Megismerhetjük White és a szovjet titkosszolgálatok kapcsolatát vizsgáló bizottság tevékenységét, a kapcsolatot alátámasztó tanúvallomásokat és White ellenérveit, a kiszivárogtatásokat és ezek hatását White kormányzati szerepére. 
Hasonlóan izgalmas fejezet foglalkozik Keynes amerikai hiteltárgyalásaival, még ha itt nincs is titkosszolgálati szál. A háború végére az Egyesült Királyság fizetési mérlege hatalmas hiányt mutatott, az országnak külső forrásokra volt szüksége, amelyeket az adott világhelyzetben csak az Egyesült Államok tudott biztosítani. E fejezetben az izgalmat a tárgyalások dinamikája, a különböző szereplők - a két kormány, a két pénzügyminisztérium, az amerikai adminisztráció és a Kongreszszus - álláspontjának alakulása, a kölcsön méretével és feltételeivel kapcsolatos változások bemutatása biztosítja.

A regényes rész a Savannah és a hármas tragédia címü fejezettel zárul. Kritikusan értékeli a Nemzetközi Valutaalap és a Világbank első közgyülésén a székhelyről, a tisztségviselők díjazásáról és a Washingtonban való folyamatos jelenlétről hozott döntéseket, amelyek Keynes véleménye szerint hozzájárultak ahhoz, hogy az így kialakított szervezet nem „a részt vevő országok együttmüködésének fóruma és tanácskozó testülete, hanem a részt vevő országok fölött álló és fölöttük uralomra törö" szervezet lett.

Az elöző fejezetekben tárgyalt megpróbáltatások hozzájárulhattak Keynes, majd White tragikus halálához. A hármas tragédia harmadik elemének a könyv az eredeti Bretton Woods-i rendszer 1971. évi összeomlását, a dollár aranyra válthatóságának megszüntetését tartja.

A záró VI. rész három fejezete - A közgazdaságtan egyes új irányzatai és a nemzetközi gazdaság rendje címmel - rövid összefoglalást ad az általános gazdasági egyensúly neoklasszikus és keynesi elméletéről, a nemzetközi gazdaság keynesi rendjéről, fejezetet szentel Lucas Keynes-kritikájának, és Keynes időszerüsége mellett érvel. A témák felsorolása is mutatja, mindez akár újabb könyv témája lehetne, és a szerző is utal rá, hogy ez a rész csak a helyzet töredékes bemutatásának tekinthetö.

A keynesi felfogás szerint - amelyet a szerző teljes mértékben oszt - az a tétel, amely szerint a szabadon működő piacokon a szereplők egyedi döntései egyensúlyt és társadalmi optimumot alakítanak ki, a lehetséges egyensúlyi helyzeteknek csak szélső esete, miután a valóságban nem teljesülnek a munkaeröpiacra vonatkozó alapfeltevések. Különböző munkanélküliségi szintekhez tartozó egyensúlyi helyzetek alakulhatnak ki, és szükség van állami beavatkozásra a társadalmilag legkedvezőbb változat létrejöttéhez. A könyvnek nem tárgya az általános elmélet, a szerző azért tartja fontosnak a rövid összefoglalást, mert alapvető azonosságot lát az állami beavatkozás indokoltsága és aközött, hogy a nemzetközi gazdasági kapcsolatokban is szükség van az egyedi nemzetállami döntéseket befolyásolni, azokat felülírni képes nemzetközi szervezet beavatkozására. Minderről a korábbi fejezetekben bemutatott Keynesművek részletes indokolást adnak, így ha nincs is a nemzetközi elméletet összefoglalóan kifejtő Keynes-publikáció, jogos Szakolczai fogalomhasználata, amikor Keynes általános nemzetközi elméletéről beszél.

A neoklasszikus egyensúlyi elmélet nem vesz tudomást a tranzakciós költségek (Coase) és az információs aszimmetria (Akerlof) tényéről, emeli ki a könyv a közgazdaság-tudomány újabb eredményei közül. Bár ezek kapcsán nem nagyon lehet érvelni az állami beavatkozás indokoltsága mellett, az állítható, hogy tényleges piaci viszonyok mellett nem feltétlenül jön létre az elmélet szerint optimális helyzetet eredményező egyensúly. 
Külön fejezet foglalkozik az állami beavatkozást elméleti alapon ellenző Lucas Keynes-kritikájával. Lucas véleménye szerint nincs kielégítő elmélet a konjunktúraciklusok magyarázatára, ha pedig az okokat nem értjük, nem mondhatjuk, hogy állami beavatkozással a ciklusok simíthatók, negatív hatásaik kiküszöbölhetők. Az sem állítható, hogy van a munkanélküliségnek természetes szintje, lehet egyensúly akár 3, akár 9 százalékos szint mellett. Ezt az érvelést a szerző szellemesen az állami beavatkozás indokává teszi, ha a piac különböző szintekre vezet, célszerü beavatkozni, hogy kisebb legyen a munkanélküliség.

A könyv Keynes időszerűségével, életművének méltatásával zárul. Mind a korábbi fejezetek, mind az összefoglaló vitákat, ellenvéleményeket is kiválthat, továbbgondolkodásra késztet, amit tudományos mủ esetén érdemnek tekintek. Arról azonban talán nem lehet vita, hogy példamutató Keynes - és a könyv szerzőjének - szemléletmódja, amely szerint a tudománynak a valós helyzetből kiindulva az egész emberiség számára legjobb helyzetet eredményező megoldások keresésére kell irányulnia.

\section{Hivatkozások}

KeynEs, J. M. [1937/1965]: A foglalkoztatás, a kamat és a pénz általános elmélete. Közgazdasági és Jogi Könyvkiadó, Budapest.

PiketTy, T. [2015]: A tőke a 21. században. Kossuth, Budapest.

Kovács Álmos

Kovács Álmos közgazdász. 